\title{
THE DETERMINANTS OF CAPITAL STRUCTURE OF MICROFINANCE INSTITUTIONS IN GHANA
}

Anthony Kyereboah-Coleman

University of Ghana Business School, Legon

\begin{abstract}
Using a panel data methodology, this study examines the determinants of capital structure of 52 microfinance institutions (MFIs) in Ghana. The empirical results show that the MFIs are highly leveraged and that their capital structure is explained partly by standard finance theory and by other unconventional variables. Specifically, the study confirms that leverage is positively related to asset tangibility, with small MFIs using short-term and large MFIs using long-term debt. Though, the findings confirm that leverage is inversely related to risk, they also suggest that some MFIs enjoy long-term debt in spite of risk, while profitability is irrelevant in explaining the capital structure decisions of MFIs. Finally, the study shows that the reputation and board independence of MFIs significantly and positively affect their capital structure decisions.
\end{abstract}

JEL G21; G32; C33

1

\section{Introduction}

Since the landmark paper by Modigliani and Miller published in 1958, debate has raged about the theoretical basis for the determinants of capital structure in firms. Financial theory has made considerable progress in efforts at explaining capital structure decisions and the variables that determine these. In this quest, various theoretical models have been proposed to explain capital structure patterns across companies and countries, and many of these models have been empirically tested in the real business world. However, most of this research has concentrated on large and listed firms, mostly in the developed world, with the consequence that other critical sectors such as microfinance, especially in developing economies, have been neglected.

Microfinance Institutions (MFIs) have evolved in recent years as tools for alleviating poverty. Understanding their operation is critical to maintaining this process of poverty reduction, the failure of which would have grave consequences for developing economies.
Following MFI successes such as the Grameen Bank of Bangladesh and Banco Solidario of Bolivia, considerable attention has been devoted to the sector by several players. These include governments, non-governmental organisations (NGOs), community activists and even some large commercial banks, which have re-channelled efforts and resources towards microfinance and microenterprise projects (Conning, 1999). Interest in the sector has touched on the objectives and methods of microfinancing (Rhyne, 1998; Morduch, 1999), but most discussions focus on the nature and scope of potential tradeoffs between the outreach potential, impact and financial selfsustainability in microfinance lending. Outreach must be recognised as a major performance indicator in the sector. Since the initial evolution of microfinance, when most microfinance operations were funded by governments, development-oriented and donor agencies, there has been a gradual but steady shift towards funding by capital markets, which has unavoidable implications for capital structure. This study therefore aims to investigate what goes into the financing decisions of MFIs. 
Conning (1999) suggests that 'all else equal, sustainable microfinance organisations that target the poorer borrowers must be less leveraged', and Kyereboah-Coleman (2007) shows that the capital structure of MFIs impacts on their performance. This paper reports on a follow-up study to determine the correlates of capital structure of MFIs. Does the capital structure of MFIs follow standard finance theory or not?

The paper is organised as follows: section two reviews the relevant literature, section three presents data collection and methodological issues, section four discusses the empirical findings, and section five concludes with the findings of the study.

\section{2}

\section{Literature review}

The term 'capital structure' can be defined as the relative amount of debt and equity employed to finance a firm's operations. It must be noted that, in finance, capital structure has been a hotly debated issue for years. One of the earliest important sources on capital structure is the work of Modigliani and Miller (1958). Their analysis of the irrelevance of capital structure to firm value is based on the premise that capital structure does not affect a firm's cash flow. Indeed, in their paper, Modigliani and Miller show that the financing decisions of firms do not affect their value. Their conclusion, however, is based on what is termed 'restrictive and unrealistic' assumptions such as a world with perfect capital markets, absence of corporate and personal taxes, and independent firms' financing decisions. Adapting these assumptions to more realistic expectations and repeating the analysis suggests that capital structure decisions do affect a firm's value. Modigliani and Miller therefore revised their initial stance in 1963. Consequently, several studies have shown that capital structure significantly affect the value of a firm (Jensen \& Meckling, 1976; Myers, 1977; Grossman \& Hart, 1982; Jensen, 1986; Williams, 1987; Harris \& Raviv, 1990; Stulz, 1990; Harris \& Raviv, 1991; Bos \& Fetherston, 1993; Myers, 2001; Boateng, 2004; Abor, 2005; KyereboahColeman, 2007).
What has remained a puzzle in this debate is the identification of an optimal capital structure and its explanatory variables. The question has always been: 'What motivates firms to choose levels of debt and equity or a combination of these?' To explain this phenomenon and understand whether there is an optimal capital structure for a firm, a number of theories have been advanced.

One of the fundamental propositions is agency theory, which states that debt financing creates an agency problem for firms. This is because debt financing leads to three difficulties:

a) It creates an incentive for stockholders to accept sub-optimal and high risk projects and in the process transfer wealth from bondholders to stockholders.

b) The presence of debt compels firms to avoid undertaking investments whose positive net present value is lower than the debt value.

c) It increases the probability of bankruptcy cost with debt level because doubt is cast on the firm's ability to generate the cash flow needed to meet its debt obligation.

From this fundamental theory emerged other popular theories such as the static trade-off and the pecking order theories. Myers (1984) advances the static trade-off theory, which explains that a firm usually decides on an ideal debt-to-equity ratio and gradually moves towards this. The implication is that some optimal capital structure exists which will enable the firm to operate efficiently and also ensure that external claims on cash flow (such as taxes, bankruptcy costs and agency costs) are reduced. 'Thus, there is a transition from Miller's (1977) postulate of tax neutrality - later refuted by DeAngelo and Masulis (1980) who introduced the concept of non-debt tax shield - to the static theory which postulates the optimum debt level as a consequence of a trade-off between tax advantages of borrowed money and financial distress costs' (De Miguel \& Pindado, 2001). In contrast, the pecking order theory suggests that the profitability of a firm affects its financing decisions, and therefore suggests that firms with no predetermined mix of debt and equity prefer internal to external financing and debt to equity if the firm issues securities. 
These theories have been used to explain the capital structure of firms. In the extant literature, both internal and external variables have been identified as relevant in influencing a firm's capital structure. These variables include firm size, profitability, risk level, type of industry, tax shield, profitability margin, firm growth, whether a firm receives subsidy, ownership control and asset tangibility. As mentioned above, most of these studies of the capital structure of firms concentrate on large and listed firms in advanced economies.

Microfinance is primarily the provision of credit to poor people, who lack access to credit from mainstream financial institutions. This kind of finance has evolved as a poverty reduction strategy in developing countries, such as Ghana. The enthusiasm with which microfinance has been greeted worldwide has led to an increase in the number of MFIs providing small credit to poor people in the developing world. The microfinance movement has been commended by both academic scholars, major development finance institutions such as the World Bank and development practitioners. Growing rapidly, the sector is moving away from its original non-profit, socially motivated agenda, with lenders seeking to reach as many of the poor as possible, to state profiteering using various techniques. The use of joint liability contracts and dynamic incentives has shown that MFIs can be profitable. This has attracted profitmotivated institutions and other regular banks into the sector. The result has been that some of these institutions are moving away from government subsidies and donor dependence to accessing funds from the capital market. This move is also motivated by the MFIs' desire to ensure institutional sustainability through minimising their subsidy and donor dependence and adopting the practices of good banking. This process has cost implications and has, therefore, further strengthened the profit agenda. The main advantage of profit is the attraction it offers to private investors into the sector. Thus, commercial microfinance lenders ought to achieve much better leverage on their equity than subsidised microlenders, allowing commercial lenders to greatly multiply the scale of outreach achieved through extra currency units contributed by donors to equity in the sector.

Obviously, these trends have implications for the capital structure of MFIs. Studies of capital structure in the microfinance sector are virtually non-existent, which is the fundamental motivation of this study. Kyereboah-Coleman (2007), in a study of capital structure and the performance of MFIs, found that MFIs are highly leveraged. Thus, an understanding of the correlates of capital structure in MFIs will contribute greatly to the on-going debate about capital structure. Are those determinants of capital structure identified in studies of large and listed firms applicable to MFIs? Do MFIs in developing countries such as Ghana exhibit the capital structure that conforms to standard finance theories? These are some of the questions this study seeks to answer.

\section{3}

\section{Data collection and methodology}

This study uses data from a sample of 52 MFIs in Ghana. These MFIs are sampled primarily according to accessibility to data and records, since MFIs are noted for being difficult to acquire data from. The data is captured from annual financial statements and personal interviews and covers a 10 year period, from 1995-2004. Analysis is carried out within a panel data framework. This is because panel data provides a relatively large number of data points and, therefore, additional degrees of freedom. We incorporate data from both cross-section and time series variables to reduce the problems associated with omitted variables, since we may not be able to fully specify a capital structure model. Variables relating to tax (such as non-tax shield and tax impact) and firm growth were not captured, due to data constraints. Thus, our basic model follows that of Delcoure (2006) and is specified as follows:

$\frac{D_{i, t}}{V_{i, t}}=\beta_{0}+Z_{i, t}^{\prime} \beta_{1}+\iota_{i, t}$

where $\mathrm{i}=1 \ldots \ldots .52 ; \mathrm{t}=1 \ldots \ldots .10$,

$\frac{D_{i, t}}{V_{i, t}}$ is a measure of debt ratios (where $D$ represents the various debt levels and $V$ representing total assets) explained below for firm $i$ at time $t$. 
$\beta_{0}$ is the intercept.

$Z_{i, t}$ is a $1 \times \mathrm{k}$ vector of observations on $k$ explanatory variables for firm $i$ at time $t$.

$\beta_{1}$ is a $\mathrm{k} \times 1$ vector of parameters.

$\iota_{i, t}$ is the disturbance term measured by

$\iota_{i, t}=\mu_{i}+v_{i, t}$,

where $\mu_{i}$ represents the unobservable individual effect and $v_{i, t}$ is the residual.

\subsection{Factors important in estimation}

In any panel data model, choice of an appropriate technique for estimating the basic model is dependent on the structure of the error term, that is:

$\iota_{i, t}=\mu_{i}+v_{i, t}$

and the correlation between the components of the error term and observed explanatory variables.

The simplest and most basic estimator of the panel data set is the pooled OLS where there are no firm specific and time effects. However, Johnson and DiNardo (1997) argue that pooled OLS estimators ignore the panel nature of the data set, and so treat observations as being serially uncorrelated for a given firm, leading to homoscedastic errors across individuals and time periods. These effects could however be negligible and unobservable if accommodated using one of two techniques.

The first technique is to reduce the number of parameters to be estimated and justify treating the individual fixed effects as drawn from some distribution. The parameters of this distribution then become the parameters to be estimated. The unobservable effects are therefore included in the error term. The variance-covariance matrix of the resulting non-spherical errors is then transformed to obtain consistent estimates of standard error. In this case, the random effects (RE) estimator is the most appropriate (Hsiao, 1989).

However, a problem arises with the RE estimator if the unobservable effects which have been included in the error term are correlated with some or all of the regressors. This simultaneity makes the RE estimation inconsistent. Thus, as a consistent alternative to the RE estimator, a second technique can be used, namely a dummy variable can be included for each firm. This estimation approach is known as the fixed effects (FE) approach and yields consistent estimates regardless of correlation between firm-specific error components and the regressors. However, the FE is less efficient than the RE estimator. This inefficiency arises because the FE estimator requires a separate parameter to be estimated for each firm in the sample, rather than the single variance estimate required for the RE estimator. In deciding which estimation method to employ, the Hausman specification test is recommended.

Hausman (1978) suggests a test to check whether individual effects are correlated with the regressors $\left(\mathrm{X}_{\mathrm{it}}\right)$. Under the null hypothesis of orthogonality, that is, no correlation between individual effects and explanatory variables, both $\mathrm{RE}$ and FE estimators are consistent, but the RE estimator is efficient while FE is not. Under the alternative hypothesis, that individual effects are correlated with the explanatory variables, the RE estimator is inconsistent and the FE estimator is consistent and efficient. Greene (1997) states that under the null hypothesis the estimates should not differ systematically. Thus, the Hausman specification test is based on a contrast vector $\mathrm{H}$ :

$\mathrm{H}=\left[\mathrm{b}^{\mathrm{GLS}}-\mathrm{b}^{\mathrm{w}}\right]^{\prime}\left[\mathrm{V}\left(\mathrm{b}^{\mathrm{w}}\right)-\mathrm{V}\left(\mathrm{b}^{\mathrm{GLS}}\right)\right]-1\left[\mathrm{~b}^{\mathrm{GLS}}-\mathrm{b}^{\mathrm{w}}\right]$

Hence, in estimating our basic model, the Hausman specification test is carried out and a choice made between RE and FE estimation. In the Hausman specification test, if the probability value of the chi-square is $\geq 0.5$, the $\mathrm{RE}$ estimation is accepted, otherwise the FE estimator is employed.

\subsection{Variable description and justification}

The dependent variable is the debt ratio as suggested in the literature. Following Titman and Wessels (1988), we use three leverage measures calculated by finding the ratio of book value of short-term debt to total assets (short-term leverage), long-term debt to total assets (long-term leverage) and total debt to total assets (total leverage). 


\subsubsection{Asset structure}

Lenders normally use tangible assets as security consistent with trade-off theory. Jensen and Meckling (1976) show that collateral serves to protect lenders from the moral hazard problem associated with shareholder-lender conflict. Also, Williamson (1988) points out that capital project financing is essentially dependent on asset tangibility. Similarly, Titman and Wessels (1988), Rajan and Zingales (1995) and Chen (2004) show that significant positive relationships exist between asset tangibility and firm debt. To measure asset tangibility, we use the ratio of net total fixed assets to total assets.

\subsubsection{Volatility of earnings}

This is a measure of risk, because according to the static trade-off theory, higher volatility of earnings increases a firm's probability of financial distress. Thus, a firm's debt ratio decreases when bankruptcy costs are higher in situations of higher earnings volatility. Studies by Marsh (1982), Bradley, Jarrell and Kim (1984), MacKie-Mason (1990) and De Miguel and Pindado (2001) find that there is an inverse relationship between a firm's financial distress cost and debt ratio. We measure our risk (earnings volatility) as the standard deviation of the first difference of the ratio of Earnings before Interest and Taxes (EBIT) to total assets. Thus,

Risk $=\left[\right.$ Std. deviation $\left.\left(\Delta \frac{E B I T}{T A}\right)\right]$

\subsubsection{Firm size}

Larger firms tend to be more diversified and are therefore able to absorb risk (Rajan \& Zingales, 1995). In addition, they tend to have easy access to credit and have more diluted ownership, leading to less control over managerial decisions. Friend and Lang (1988) find that, though, managers may influence debt ratios in order to protect their personal investment in a company, a firm's debt maturity choice is less dependent on size. In this study we use the natural log of total assets as a measure of size.

\subsubsection{Profitability}

Concerning profitability, Jensen's (1986) theory of the agency cost of financial structure considers debt as a disciplining device which compels managers to increase shareholders' wealth rather than building empires. Therefore, studies on the links between capital structure and firm profitability have shown that there is an inverse relationship between capital structure and profitability (Friend \& Lang, 1988; Rajan \& Zingales, 1995; Wald, 1999; Chen, 2004). Return on total assets (ROA) measured by the ratio of EBIT to total assets is our measure of profitability.

\subsubsection{Other variables}

In addition to these variables drawn from standard finance theory, we also employ other unconventional variables that could impact on capital structure, particularly in the microfinance sector. First, we use the age of the firm as a proxy for reputation, on the premise that age should have a positive relationship with debt. An old firm generally is a reputable firm that with a reputation for reliability that commands trust. Firm age is captured using the number of years the institution has been in operation starting from the year of incorporation.

We also use board characteristics such as size, independence, CEO duality and CEO tenure as possible explanatory variables. These translate into agency problems and costs with further implication for firms' capital structure. For the size of the board, we use the number of board members, and for independence of the board the ratio of non-executive board members to board size. John and Senbet (1998) indicate that agency costs are higher when a board is dominated by executive members. In contrast, an independent board ensures effective monitoring and attracts private investment which has implications for debt levels. In the case of CEO duality, agency costs are deemed higher when a CEO doubles as a board chairman, and this discourages private investment and debt. In our study, this is a dummy variable which takes a value of 1 when the CEO also acts as board chairman and 0 otherwise. Finally, we use the tenure of the CEO as our last explanatory variable. 
4

\section{Empirical findings}

\subsection{Summary statistics}

The oldest MFI in the sample has been in existence for 41 years; on average the firms have been operating for 18 years. In size the MFIs show a wide spread, with a relatively high standard deviation of $2.67+\mathrm{e} 07$. Most of these MFIs have a greater percentage (about 71 percent) of their assets in current form, though some have 85 percent of their assets as fixed assets. Most of these assets are financed with debt at a mean leverage of 0.76 . Significantly, the leverage in these institutions is mainly driven by long-term rather than short-term debts. The MFIs appear to be moderately volatile in income flow, which suggests some degree of stability, with implications for lower bankruptcy costs and greater sustainability. This is supported by results for profitability performance of ROA, though these show a wider spread. Concerning institutional governance, the MFIs have a mean board size of 6 members, with a maximum of 10 members. The independence of these boards is relatively low, according to the mean board composition of 0.48 . This implies that about 52 percent of the board members are executive directors. The leadership structure is equally divided, between separating CEO and chairman roles and a combination of the two. 50 percent of the MFIs have the two positions carried out by one person and the other 50 percent have two separate office holders. The longest CEO tenure is 4 years but most of them serve a term of up to 3 years. A summary is presented in Table 1 .

Table 1

Summary of MFI statistics

\begin{tabular}{|c|c|c|c|c|c|}
\hline Variable & Obs & Mean & Std. Dev & Min & $\operatorname{Max}$ \\
\hline Short-term leverage & 520 & 0.35 & 0.29 & 0.0004 & 0.99 \\
\hline Long-term leverage & 520 & 0.41 & 0.30 & 0.0000435 & 0.88 \\
\hline Leverage (total) & 520 & 0.76 & 0.23 & 0.01 & 1.00 \\
\hline Asset tangibility & 520 & 0.29 & 0.20 & 0.03 & 0.85 \\
\hline Earnings volatility & 520 & 0.21 & 0.38 & -0.60 & 0.70 \\
\hline Total assets & 520 & $1.22 \mathrm{e}+07$ & $2.67 \mathrm{e}+07$ & 129470.00 & $1.35 \mathrm{e}+08$ \\
\hline Return on assets & 520 & 0.39 & 1.52 & 0.06 & 35.00 \\
\hline Firm age & 520 & 17.83 & 5.02 & 10.00 & 41.00 \\
\hline Board size & 520 & 6.23 & 1.83 & 3.00 & 10.00 \\
\hline Board independence & 520 & 0.48 & 0.12 & 0.30 & 0.70 \\
\hline CEO duality & 520 & 0.50 & 0.50 & 0.00 & 1.00 \\
\hline CEO tenure & 520 & 2.85 & 0.72 & 2.00 & 4.00 \\
\hline Log of firm age & 520 & 14.52 & 1.90 & 11.77 & 18.72 \\
\hline Log of total assets & 520 & 2.84 & 0.27 & 2.30 & 3.71 \\
\hline
\end{tabular}




\subsection{Regression results}

Table 2 represents the regression results.

\subsubsection{Asset tangibility}

Consistent with the static trade-off theory, shortterm, long-term and total leverage are positively correlated with asset tangibility. The argument is that tangible assets are used as collateral as a source of security for lenders in the event of financial distress. Jensen and Meckling (1976) argue that collateral protects lenders from the moral hazard problem caused by shareholderlender conflict. The use of tangible assets as collateral normally reduces lenders' risk. While both short-term and total leverage are significant at five percent probability level, longterm leverage is not. A possible explanation is that in most developing countries like Ghana, financial institutions regard short-term lending as relatively rewarding as compared to longterm debt. This invariably makes long-term a limited option for several organisations. MFIs, considering their historical antecedents and social orientation, are likely to ward off longterm lenders.

\subsubsection{Earnings volatility (risk)}

Once again, the trade-off theory stipulates that a higher risk increases the probability of financial distress, and so higher bankruptcy costs result in the impact of higher earnings volatility being negative on leverage. The study finds that there is a negative correlation between short-term and total leverage and earnings volatility (risk). The results of the study with regards to short-term and total leverage are consistent with other studies (e.g. Marsh, 1982; Bradley et al., 1984; MacKie-Mason, 1990; De Miguel \& Pindado, 2001), though total leverage is insignificant. However, the study also shows a significant positive correlation between institutional risk and long-term leverage, which contradicts standard finance theory. A possible reason could be the willingness of donor agencies to lend to such institutions in the interest of a social rather than financial agenda. This is a plausible explanation because, though most of these institutions are targeting a double bottom-line, some are heavily tilted towards their social mission at the expense of financial sustainability.

\subsubsection{Firm size}

Studies have found this variable rather inconclusive. While some find a positive relationship with leverage, others find a negative correlation. The pecking order theory suggests that larger firms exhibit lower information asymmetry and are therefore able to issue more equity, compared to small companies. Consistent with the findings of Titman and Wessels (1988), this study finds a negative relationship between short-term and total leverage and firm size. While short-term leverage is statistically significant, total leverage is not. The implication is that small firms use short-term leverage as suggested by Marsh (1982). In contrast, also supporting the findings of Marsh (1982), longterm leverage is positively correlated with firm size, probably because large firms have relatively more diluted ownership and so lose control over managerial decisions.

\subsubsection{Profitability}

At a glance, the pecking order theory seems applicable to short-term leverage because of its negative relationship with profitability, whiles the others show positive signs. However, this effect on MFIs' leverage levels is insignificant.

\subsubsection{Age of firm}

Using age as a proxy for reputation, the study shows that firms with good reputations attract investors and short-term debt in particular. Interestingly, the results show that the older the firm (the higher the reputation), the less the firm attracts long-term debt. Firms rather employ more short-term debt.

\subsubsection{Institutional governance}

Since size of board is inconclusively related to all types of leverage, its effects on MFI structures are insignificant. The independence of the board however is an attraction for investors. Thus, short-term, long-term and total leverage are positively related to board independence, though short-term leverage is insignificant at 5 percent. The more independent a board is, the more shareholders feel their interest is protected 
and thus encourage debt in the operations of the MFI. While CEO duality does not appear to influence either short-term or total leverage, it is negatively related to long-term leverage. Indeed, in situations where the CEO doubles as the chairman, agency cost increases and has an adverse impact on the MFI's ability to attract long-term debt. Finally, the study shows that CEOs with shorter tenure enable MFIs to attract short-term debt whiles MFIs with longer tenure for CEOs attract long-term debt. This is essentially due to the fact that a shorter tenure leads to frequent changes in leadership which obviously has implications for a firm's policy and direction. Hence, investors are willing to commit long-term debt to the care of a firm only when satisfied that there will be less frequent changes in top management. However, the t-statistics of -1.61 and 1.53 for short-term and long-term leverage respectively in relation to CEO tenure appear rather low; the F-statistics and p-values make these acceptable in the estimation.

Table 2

Regression results

\begin{tabular}{|c|c|c|c|}
\hline \multirow[b]{2}{*}{ Variable } & \multicolumn{3}{|c|}{ Dependent variable } \\
\hline & $\begin{array}{l}\text { Short-term leverage } \\
\text { (FE estimates) }\end{array}$ & $\begin{array}{l}\text { Long-term leverage } \\
\text { (RE estimates) }\end{array}$ & $\begin{array}{l}\text { Total leverage } \\
\text { (RE estimates) }\end{array}$ \\
\hline Asset tangibility & $\begin{array}{l}0.2596891 \\
(3.18)^{* *}\end{array}$ & $\begin{array}{l}0.0037977 \\
(0.04)\end{array}$ & $\begin{array}{l}0.2533483 \\
(3.73)^{* *}\end{array}$ \\
\hline Earnings volatility & $\begin{array}{l}-0.0599206 \\
(-1.89)^{* *}\end{array}$ & $\begin{array}{l}0.0582923 \\
(1.79)^{* *}\end{array}$ & $\begin{array}{l}-0.0051144 \\
(-0.20)\end{array}$ \\
\hline Log of total assets (size) & $\begin{array}{l}-0.0634865 \\
(-6.56)^{* *}\end{array}$ & $\begin{array}{l}0.0471971 \\
(4.93)^{* *}\end{array}$ & $\begin{array}{l}-0.0045626 \\
(-0.60)\end{array}$ \\
\hline Return on assets & $\begin{array}{l}-0.0021889 \\
(-0.28)\end{array}$ & $\begin{array}{l}0.004655 \\
(0.58)\end{array}$ & $\begin{array}{l}0.0005246 \\
(0.08)\end{array}$ \\
\hline Log of firm age & $\begin{array}{l}0.5156483 \\
(7.48)^{* *}\end{array}$ & $\begin{array}{l}-0.02830497 \\
(-5.59)^{* *}\end{array}$ & $\begin{array}{l}0.0440444 \\
(1.09)\end{array}$ \\
\hline Board size & $\begin{array}{l}0.003356 \\
(0.47)\end{array}$ & $\begin{array}{l}-0.0039486 \\
(-0.53)\end{array}$ & $\begin{array}{l}-0.0008045 \\
(-0.14)\end{array}$ \\
\hline Board independence & $\begin{array}{l}0.0473919 \\
(0.46)\end{array}$ & $\begin{array}{l}0.2816785 \\
(2.67)^{* *}\end{array}$ & $\begin{array}{l}0.2905328 \\
(3.44)^{* *}\end{array}$ \\
\hline CEO duality & $\begin{array}{l}0.0297935 \\
(1.23)\end{array}$ & $\begin{array}{l}-0.066116 \\
(-2.63)^{* *}\end{array}$ & $\begin{array}{l}-0.0269775 \\
(-1.34)\end{array}$ \\
\hline CEO Tenure & $\begin{array}{l}-0.0285673 \\
(-1.61)^{* *}\end{array}$ & $\begin{array}{l}0.0284905 \\
(1.53)^{* *}\end{array}$ & $\begin{array}{l}-0.0051798 \\
(-0.35)\end{array}$ \\
\hline Constant & $\begin{array}{l}-0.2298125 \\
(-1.17)\end{array}$ & $\begin{array}{l}0.353496 \\
(2.04)^{* *}\end{array}$ & $\begin{array}{l}0.5237044 \\
(3.79)^{* *}\end{array}$ \\
\hline R-squared & 0.4335 & 0.2869 & 0.0619 \\
\hline No. of obs. & 520 & 520 & 520 \\
\hline Test of prob. & $\begin{array}{c}F(9,501)=10.72 \\
{[0.0000]}\end{array}$ & $\begin{array}{c}\text { Wald Chi2 }(9)=88.49 \\
{[0.0000]}\end{array}$ & $\begin{array}{c}\text { Wald Chi2 }(9)=32.01 \\
{[0.0002]}\end{array}$ \\
\hline Hausman test & $\begin{array}{c}\text { Chi2 }(9)=14.06 \\
{[0.1201]}\end{array}$ & $\begin{array}{c}\text { Chi2 }(9)=6.29 \\
{[0.7103]}\end{array}$ & $\begin{array}{c}\text { Chi2 }(9)=4.81 \\
{[0.8504]}\end{array}$ \\
\hline
\end{tabular}

Note: All regressions include a constant. t-statistics are in parenthesis and p-values in square bracket. 
5

\section{Conclusion}

This study aimed at identifying the determinants of capital structure of MFIs in Ghana, and to ascertain whether standard finance theory explains their financing decisions. This latter aim is especially important, considering the changing pattern of financing of MFIs, which has implications for their capital structure. A sample of 52 MFIs was selected from Ghana and data obtained for a 10 year period from 1995-2004. Analysis was carried out within a panel data framework. The results show that leverage, irrespective of its maturity period, is positively related to MFIs' asset tangibility. Similarly, the results confirm the finding of other studies that leverage is inversely related to firm risk. However, this study contradicts standard finance theory, since its results suggest that some MFIs could still use long-term debt in spite of high risk. Again, consistent with other findings, the study shows that small firms tend to use short-term leverage while large firms employ long-term leverage. Furthermore, the study finds that profitability is irrelevant in a MFI's capital structure.

The results for more unconventional variables show that MFIs with good reputation enjoy shortterm leverage, and that older MFIs (with good reputations) employ more short-term than longterm debt. Institutional governance variables produce mixed results; the independence of MFIs' boards is crucial in determining capital structure, with a highly significant positive correlation found between board independence and all three types of leverage, and CEO duality impacts negatively on long-term leverage because of increased agency costs. Also, shorter tenure for the CEO encourages short-term debt and longer tenure attracts long-term debt.

In conclusion, the capital structure of MFIs is therefore explained partly by standard finance theory and certain unconventional variables. These findings have important policy implications, but the relatively small sample and short period covered serve as the main limitation of this study. However, these limitations do not compromise the validity of the findings.

\section{References}

1 ABOR, J. (2005) "The effect of capital structure on profitability: An empirical analysis of listed firms in Ghana", The Journal of Risk Finance, 6(5): 438-447.

2 BOATENG, A. (2004) "Determinants of capital structure: Evidence from international joint ventures in Ghana", International Journal of Social Economics, 31(1/2): 56-66.

3 BOS, T. \& FETHERSTON, T.A. (1993) "Capital structure practices on the specific firm”, Research in International Business and Finance, 10: 53-66.

4 BRADLEY, M.; JARRELL, G.A. \& KIM, E.H. (1984) "On the existence of an optimal capital structure", Journal of Finance, 39: 857-878.

5 CHEN, J.J. (2004) "Determinants of capital structure of Chinese listed companies", Journal of Finance, 56: 87-130.

6 CONNING, J. (1999) “Outreach, sustainability and leverage in monitored and peer-monitored lending", Journal of Development Economics, 60: 51-77.

7 DEANGELO, H. \& MASULIS, R.W. (1980) "Optimal capital structure under corporate and personal taxation", Journal of Financial Economics, 8: 3-29.

8 DELCOURE, N. (2006) "The determinants of capital structure in transitional economies", International Review of Economics and Finance (forthcoming).

9 DE MIGUEL, A. \& PINDADO, J. (2001) "Determinants of capital structure: New evidence from Spanish panel data", Journal of Corporate Finance, 7: 77-99.

10 FRIEND, I. \& LANG, A. (1988) “An empirical test of the impact of managerial self-interest on corporate capital structure", Journal of Finance, 43: 271-281.

11 GREEN, W. (1997) Econometric Analysis (3 ${ }^{\text {rd }}$ ed.) Prentice-Hall: Eaglewood Cliffs, NJ.

12 GROSSMAN, S.J. \& HART, O. (1982) "Corporate financial structure and managerial incentives", In McCall, J. (ed.) The Economics of Information and Uncertainty, University of Chicago Press: Chicago.

13 HARRIS, M. \& RAVIV, A. (1991) "The theory of capital structure", Journal of Finance, American Finance Association, 46(1): 295-335

14 HARRIS, M. \& RAVIV, A. (1990) "Capital structure and the informational role of debt", Journal of Finance, 45: 321-345.

15 HAUSMAN, J. (1978) "Specification tests in econometrics", Econometrica, 46: 1251-71.

16 HSIAO, C. (1989) "Analysis of panel data", Econometric Society Monographs, Cambridge University Press: New York. 
17 JENSEN, M.C. (1986) "Agency cost of free cash flow, corporate finance and takeovers", American Economic Review, 76: 23-339.

18 JENSEN, M. \& MECKLING, W. (1976) "Theory of the firm: Managerial behaviour, agency cost and ownership structure", Journal of Financial Economics, 43: 271-281.

19 JOHN, K. \& SENBET, L.W. (1998) "Corporate governance and board effectiveness", Journal of Banking and Finance, 22: 371-403.

20 JOHNSTON, J. \& DINARDO, J. (1997) Econometrics Methods (4 ${ }^{\text {th }}$ ed.) McGraw Hill: New York.

21 KYEREBOAH-COLEMAN, A. (2007) "The impact of capital structure on the performance of microfinance institutions", The Journal of Risk Finance, 8(1): 56-71.

22 MACKIE-MASON, J.K. (1990) "Do taxes affect corporate financing decisions?", Journal of Finance, 45: 1471-1493.

23 MARSH, P.R. (1982) "The choice between equity and debt: An empirical study", Journal of Finance, 37: 121-144.

24 MODIGLIANI, F. \& MILLER, M.H. (1958) "The cost of capital, corporate finance and the theory of investment", American Economic Review, 48: 261297.

25 MODIGLIANI, F. \& MILLER, M.H. (1963) "Corporate income taxes and the cost of capital: A correction", American Economic Review, 53: 433443.

26 MORDUCH, J. (1999) "The microfinance promise", Journal of Economic Literature, 37: 15691614.
27 MILLER, M.H. (1977) "Debts and taxes", Journal of Finance, 32: 261-276

28 MYERS, S.C. (2001) "Capital structure", Journal of Economic Perspectives, 15(2): 81-102.

29 MYERS, S.C. (1984) "The capital structure puzzle”, Journal of Finance, 39: 575-592.

30 MYERS, S.C. (1977) "The determinants of corporate borrowing”, Journal of Financial Economics, 5: 147-175.

31 RAJAN, R.G. \& ZINGALES, L. (1995) "What do we know about capital structure? Some evidence from international data", Journal of Finance, 50: 1421-1460.

32 RHYNE, E (1998) “The yin and yang of microfinance: Reaching the poor and sustainability", Microbanking Bulletin, 2.

33 STULZ, R. (1990) "Managerial discretion and optimal financing policies", Journal of Financial Economics, 20: 3-26.

34 TITMAN, S. \& WESSELS, R. (1988) "The determinants of capital structure choice", The Journal of Economic Theory, 42: 209-243.

35 WALD, J.K. (1999) "How firm characteristics affect capital structure: An international comparison", Journal of Financial Research, 22: 161-187.

36 WILLIAMS, J. (1987) "Perquisites, risk and capital structure", Journal of Finance, 42: 29-49.

37 WILliamSON, O.E. (1988) "Corporate finance and corporate governance", Journal of Finance, 43: 567-591. 